The University of Maine

\title{
DigitalCommons@UMaine
}

Marine Sciences Faculty Scholarship

School of Marine Sciences

$3-1-2011$

\section{Precious Corals (Coralliidae) from North-Western Atlantic Seamounts}

\author{
A. Simpson \\ Les Watling \\ University of Maine - Main, watling@maine.edu
}

Follow this and additional works at: https://digitalcommons.library.umaine.edu/sms_facpub

\section{Repository Citation}

Simpson, A. and Watling, Les, "Precious Corals (Coralliidae) from North-Western Atlantic Seamounts" (2011). Marine Sciences Faculty Scholarship. 97.

https://digitalcommons.library.umaine.edu/sms_facpub/97 


\title{
Precious corals (Coralliidae) from north-western Atlantic Seamounts
}

\author{
ANNE SIMPSON ${ }^{1}$ AND LES WATLING ${ }^{1,2}$ \\ ${ }^{1}$ Darling Marine Center, University of Maine, Walpole, ME 04573, USA, ${ }^{2}$ Department of Zoology, University of Hawaii at Manoa, \\ Honolulu, HI 96822, USA
}

\begin{abstract}
Two new species belonging to the precious coral genus Corallium were collected during a series of exploratory cruises to the New England and Corner Rise Seamounts in 2003-2005. One red species, Corallium bathyrubrum sp. nov., and one white species, C. bayeri sp. nov., are described. Corallium bathyrubrum is the first red Corallium to be reported from the western Atlantic. An additional species, C. niobe Bayer, 1964 originally described from the Straits of Florida, was also collected and its description augmented.
\end{abstract}

Keywords: Corallium, deep-water corals, Corallium niobe, Corallium bathyrubrum sp. nov., Corallium bayeri sp. nov., New England Seamount Chain, Corner Rise Seamount Group, western Atlantic Ocean

Submitted 10 October 2009; accepted 23 March 2010; first published online 5 July 2010

\section{INTRDDUCTION}

The genus Corallium is notable for containing species known as 'precious coral' that have been harvested by humans for centuries for both decorative and medicinal use (Liverino, 1983). Concerns about over-harvesting of Corallium populations prompted the United States in 2007 and again in 2009 to propose listing all Corallium spp. under the Convention on International Trade in Endangered Species of Wild Fauna and Flora (CITES) Appendix 2. This listing would afford maximal protection under international law to all Corallium and Paracorallium species.

Corallium species are found in most oceans, including the Atlantic Ocean (6 species), the Mediterranean Sea (1), the Indian Ocean (2), and the Pacific Ocean (18), at depths ranging from $\sim 7$ to $1500 \mathrm{~m}$ (Bayer \& Cairns, 2003). Populations of Corallium large enough to support commercial harvest are generally found north of $19^{\circ} \mathrm{N}$. These include seven species harvested in the Western Pacific and the primarily Mediterranean Corallium rubrum. The latter species occurs mostly at shelf depths $(30-200 \mathrm{~m})$ but is occasionally found in deeper water $(60-200 \mathrm{~m})$ in the eastern Mediterranean, and along the Atlantic coasts of Europe and Africa from southern Portugal to the Cape Verde Islands (Carpine \& Grasshoff, 1975). In the Western and Central Pacific various species of Corallium can be found from Japan to the northern Philippines $\left(19^{\circ} \mathrm{N}-36^{\circ} \mathrm{N}\right)$ and along the Hawaiian island chain to the southern Emperor Seamounts $\left(20^{\circ} \mathrm{N}\right.$ to $\left.36^{\circ} \mathrm{N}\right)$ (Grigg, 1994). Corallium boshuense, C. elatius, C. japonicum, C. konojoi, C. pusillum and C. sulcatum are found in Japanese waters. The Hawaiian Island archipelago and Emperor Seamounts species include C. abyssale, C. lauuense, C. niveum, C. regale, C. secundum and one or more new

Corresponding author:

L. Watling

Email: watling@hawaii.edu species (Bayer, 1956; Parrish \& Baco, 2007). Central Pacific Corallium beds are found at two depths, $90-575 \mathrm{~m}$ and 1000-1500 m (Grigg, 1994; Baco \& Shank, 2005) separated vertically by an oxygen minimum zone that drops to about $1 \mathrm{ml} / \mathrm{l}$. According to CITES (2007) isolated colonies of Corallium sp. have been reported off Australia, the Solomon Islands, Vanuatu, Fiji, Kiribati, Tonga, Samoa and the Cook Islands at 200-500 $\mathrm{m}$ depth, in international waters on the New England Seamounts (Atlantic Ocean), and in waters of the United States off Florida (in Lophelia beds in the Florida Straits), California (Davidson Seamount), Alaska (Gulf of Alaska Seamounts), Guam and three locations in American Samoa.

Including the two new species described herein, the genus Corallium currently comprises 26 species, with the majority endemic to the Pacific Ocean. The following six species have been previously reported from the Atlantic: C. johnsoni Gray, 1860; C. maderense (Johnson, 1899); C. medea Bayer, 1964; C. niobe Bayer, 1964; C. rubrum (Linneaus, 1758) and C. tricolor (Johnson, 1899).

This paper provides descriptions of two new Corallium species from the Atlantic that were collected during a series of research cruises to the New England Seamount Chain and Corner Rise Seamount group from 2003 to 2005. In addition, we collected and add to the description of C. niobe, originally described by Bayer (1964) from the Straits of Florida. Corallium niobe was often seen in the same locations as $C$. bathyrubrum sp. nov. and C. bayeri sp. nov., and was even found growing on the dead skeleton of the latter species.

\section{MATERIALS AND METHODS}

Corallium specimens were collected during the 'Mountains-in-the-Sea I and II' expeditions to the New England Seamounts in 2003 and 2004, and the 'Deep Atlantic Stepping Stones' (DASS) expedition to the New 
England and Corner Rise Seamounts in 2005. Additional material from the New England Seamounts was obtained in 2005 during the 'From the Canyons to Balanus Seamount' (CANYBAL) research cruise. Summaries of the Mountains-in-the-Sea I and II and DASS expeditions are available on the NOAAOcean Exploration Program website (currently www.oceanexplorer.noaa.gov). CANYBAL cruise details are available on the National Undersea Research Center website (http://www.nurc.uconn.edu/about/events/ eventoo13/index.htm).

Whole or partial coral colonies were collected by the remotely operated vehicle (ROV) 'Hercules' or manned submersible 'Alvin' using the vehicle's hydraulic manipulator arm. Specimens were immediately transferred in situ to a thermally insulated 'biobox' for storage until completion of the dive. Shortly after recovery by the surface vessel, collected material was removed from the bioboxes and placed in cold water for short-term storage before being photographed and processed for long-term storage. Small pieces of tissue were removed for genetic and reproductive studies and the remainder of the colony was fixed in $4 \%$ buffered formalin for 12 hours. Following fixation colonies were transferred to $70 \%$ ethanol for preservation.

A commercial sodium hypochlorite solution (Clorox bleach) was used to remove coral tissue from the inorganic axis and sclerites to allow examination of these structures. Following successive rinses with deionized water to remove any remaining bleach, sclerites and small pieces of the axis were air dried in preparation for viewing with scanning electron microscopy (SEM). Larger pieces containing coenenchyme and polyp tissue were critical point dried to reduce shrinkage artefacts.

All material for SEM was mounted on black carbon tape coated stubs, secured with silver paint if necessary, and coated with a layer of gold-palladium film by sputtering under vacuum. Digital images were obtained using a Hitachi S-80o or S-480o scanning electron microscope. All SEM images were prepared for publication using Adobe Photoshop Elements 4.0 in accordance with current scientific image processing guidelines. All types deposited at Yale Peabody Museum (YPM) or US National Museum (USNM).

\section{SYSTEMATICS \\ Class ANTHOZOA \\ Subclass OCTOCORALLIA Haeckel, 1866 Order ALCYONACEA Verrill, 1866 \\ Family CORALLIIDAE Lamouroux, 1812 Genus Corallium Cuvier, 1798}

\section{SYNONYMY}

See Bayer $(1956,1964)$

\section{TYPE MATERIAL}

'Madrepora rubra Linnaeus, 1758 (by subsequent monotypy, the first species being assigned by Lamarck, 1801)' (Bayer 1956: 73).

\section{DIAGNOSIS}

After Bayer (1956, 1996): branching dimorphic Scleraxonia with solid, calcareous axis derived from a matrix of sclerites embedded in rectilinear calcite. Sclerites mostly 6-, 7-, and/ or 8-radiates, varying from regular to highly modified forms including double clubs, spindles, rods, and crosses.

\section{ADDITIONAL SPECIES}

Corallium abyssale Bayer 1956, C. bathyrubrum sp. nov., C. bayeri sp. nov., C. borneense Bayer 1950, C. boshuensis Kishinouye 1903, C. ducale Bayer 1955, C. elatius (Ridley, 1882), C. halmaheirense Hickson 1907, C. kishinouyei Bayer 1996, C. imperiale Bayer 1955, C. johnsoni (Gray, 1860), C. konojoi Kishinouye 1903, C. lauuense Bayer 1956, C. maderense (Johnson, 1899), C. medea Bayer 1964, C. niobe Bayer 1964, C. niveum Bayer 1956, C. porcellanum Pasternak 1981, C. pusillum Kishinouye 1903, C. regale Bayer 1956, C. reginae Hickson 1907, C. secundum Dana 1846, C. sulcatum Kishinouye 1903, C. tricolor (Johnson 1899), C. variable Thomson \& Henderson 1906.

\section{Corallium bathyrubrum sp. nov.} (Figures 1-4)

\section{TYPE MATERIAL}

Holotype: Kelvin Seamount, Station KEL 407-1, $38^{\circ} 46.978^{\prime} \mathrm{N}$ $63^{\circ} 57.767^{\prime} \mathrm{W}, 2253 \mathrm{~m}, 19$ May 2004, whole colony with holdfast, $29 \mathrm{~cm}$ in height and $27.5 \mathrm{~cm}$ wide, YPM 38610.

Paratypes: Kelvin Seamount, Station KEL 401-1, $38^{\circ} 46.493^{\prime} \mathrm{N} 63^{\circ} 57.926^{\prime} \mathrm{W}, 2417 \mathrm{~m}, 19$ May 2004, whole colony with holdfast, $16 \mathrm{~cm}$ in height and $14 \mathrm{~cm}$ wide, YPM 38611; Kelvin Seamount, Station KEL 603-3, $38^{\circ} 45.47^{\prime} \mathrm{N}$ $64^{\circ} 05.50^{\prime} \mathrm{W}, 2572 \mathrm{~m}, 31$ August 2005, broken branch pieces, $12-20 \mathrm{~cm}$ in length, YPM 38613; Nashville Seamount, Station NAS 201-1, $34^{\circ} 28.19^{\prime} \mathrm{N} 56^{\circ} 43.77^{\prime} \mathrm{W}, 2529 \mathrm{~m}, 25$ August 2005, single branch, $23 \mathrm{~cm}$ in length, USNM No. 1135989; Nashville Seamount, Station NAS 201-3, $34^{\circ} 28.19^{\prime} \mathrm{N} 56^{\circ} 43.77^{\prime} \mathrm{W}, 2529 \mathrm{~m}, 25$ August 2005, three main branches from whole colony, $20 \mathrm{~cm}$ in height in length $12.5 \mathrm{~cm}$ wide, YPM 38612; Pickett Seamount, Station PIC $101-5,39^{\circ} 39.113^{\prime} \mathrm{N} 65^{\circ} 56.479^{\prime} \mathrm{W}, 2085 \mathrm{~m}, 28$ October 2005 , piece of a larger branch, $10 \mathrm{~cm}$ in length and $6 \mathrm{~cm}$ wide, USNM No. 1135988.

\section{ETYMOLOGY}

The specific name bathyrubrum is derived from a combination of the Greek words bathys = deep and rubrum = red, which are descriptive of this deep-dwelling, red coral species.

\section{DIAGNOSIS}

Principally dichotomous branching in one plane. Autozooids distributed mainly on one side of colony, occurring as single polyps or in small groups of two or more. Contracted autozooids tall and cylindrical, with 8 longitudinal grooves extending from apex to base. Siphonozooids form low, rounded mounds $<_{1} \mathrm{~mm}$ in diameter. Coenenchyme overlying the axis thin. Colony surface appearance ranges from faintly longitudinally grooved on main trunk and larger branches to prominently papillate and lacking longitudinal grooves on smaller branches and branchlets. Axis superficially smooth and without pits. Predominant sclerite types various radiate forms, including 6-, 7-, and 8-radiates; most highly modified. Irregular sclerite forms common. Spiny rods and spindles occur in tentacles and pharynx, respectively. Both tissue and sclerites appear pink. Axis deep pink to red. 

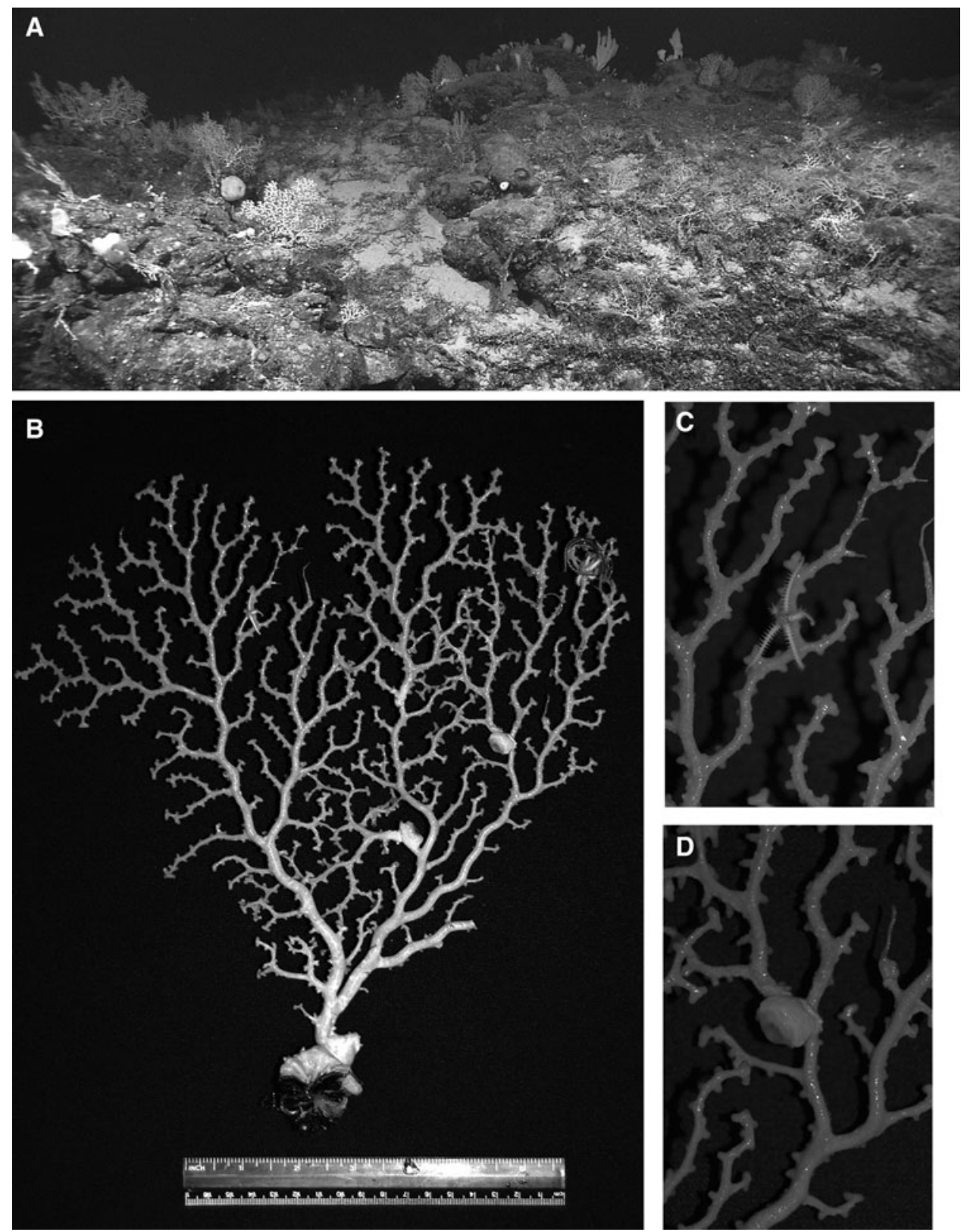

Fig. 1. Corallium bathyrubrum sp. nov. (A) In situ view of Corallium colonies on Kelvin Seamount at $\sim 2250 \mathrm{~m}$; (B) holotype colony photographed in the laboratory aboard ship; (C) close-up view of holotype branches with benthic ophiuroid; (D) close-up view of Amphianthus sp. on holotype.

\section{DESCRIPTION}

Holotype: uniplanar colony with 4 th order, primarily dichotomous branching (Figure 1). Maximum colony height and width $29 \mathrm{~cm}$ and $27.5 \mathrm{~cm}$, respectively. Holdfast at colony base wraps around Desmophyllum dianthus (Esper, 1794) skeleton with a thin, calcareous tissue layer. Main colony 'trunk' or axis nearly circular in cross-section and measures $8.5 \mathrm{~mm}$ in diameter near its base. The 'trunk' extends for $25 \mathrm{~mm}$ and then splits into two stout primary (1st order) branches that are approximately circular in cross-section and measure $5.8 \mathrm{~mm}$ and $6.3 \mathrm{~mm}$ in diameter at their origin. Branches taper from base to tip and bifurcate along their length up to the 4 th order level of branching. Many branches have a flattened appearance on autozooid-bearing side of colony produced by the growth of coenenchymal tissue overlying axis (Figure 2A). A shallow, central groove may also be present on polyp-bearing face of larger branches (Figure $2 \mathrm{~B}$, arrow). The groove, formed by parallel ridges of thickened coenenchyme, runs along outer branch edges and surrounds a very thin, polyp-free area of coenenchyme that extends along centreline of branch surface. Branchlets arise from all 1st, 2nd, and 3 rd order branches (4th order branches are distal branchlets). Secondary and 3 rd order branches nearly circular to slightly oval in cross-section and range in diameter from $1.9 \mathrm{~mm}$ to $5.2 \mathrm{~mm}$. Branchlets $1.0 \mathrm{~mm}$ to $1.6 \mathrm{~mm}$ in diameter near their origin and similar in cross-sectional appearance to branches but progressively flatten towards distal tips.

Autozooid polyps generally tall and cylindrical, becoming wider toward the base. Contracted autozooids $1.8-2 \mathrm{~mm}$ in height, and $1.5-1.7 \mathrm{~mm}$ at the base (Figure 2). In contracted state tentacles fold over the oral disc and their bases form an 8 -lobed aperture at the distal end of the polyp. Grooves 

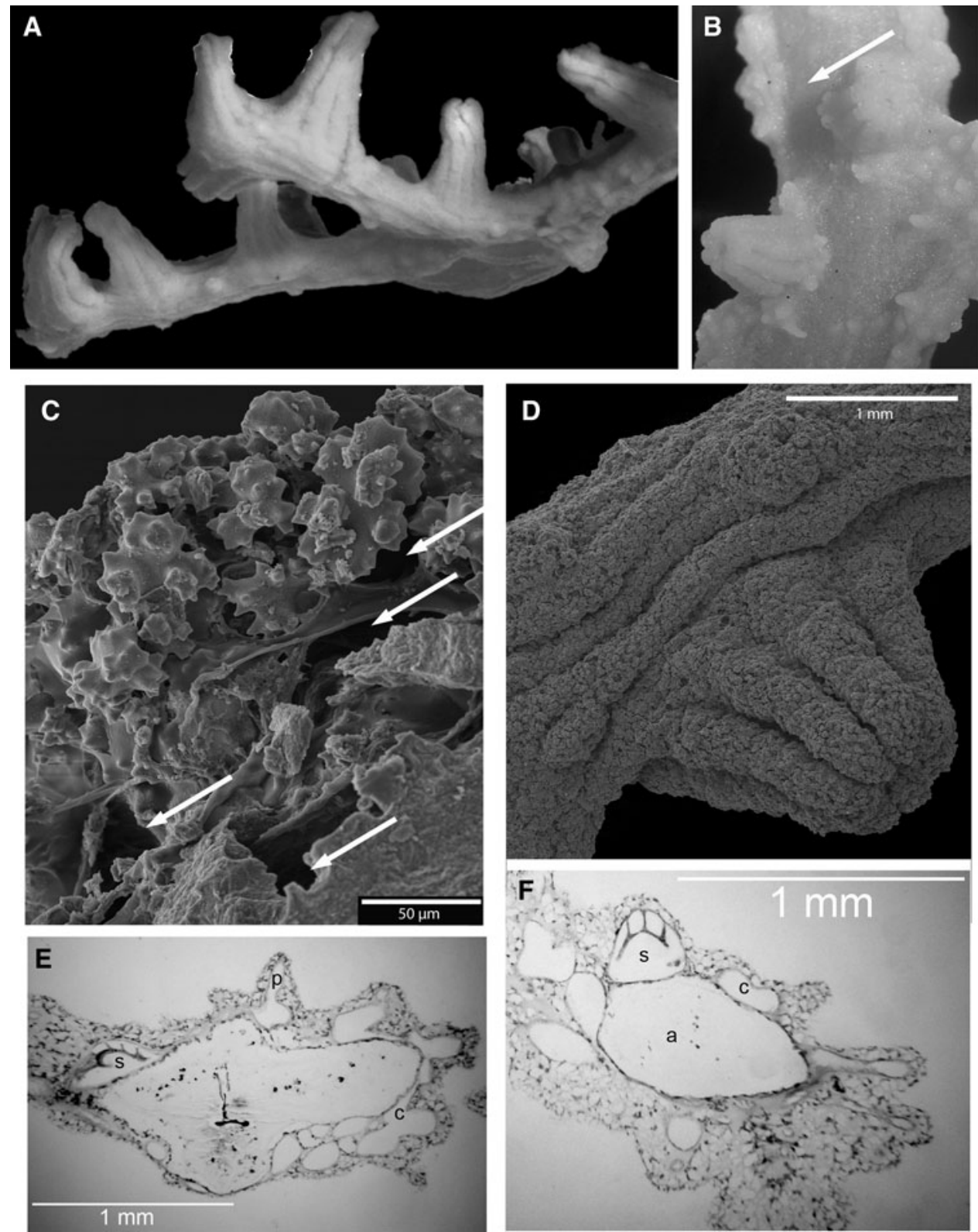

Fig. 2. Corallium bathyrubrum sp. nov. (A) Close-up view of polyps on holotype colony (showing branches with flattened aspect); (B) branch with central groove (arrow) and numerous papillae; (C) scanning electron microscopy (SEM) image of solenial channels connecting to adjacent papillae and siphonozooids; (D) SEM image of an autozooid and siphonozooid; (E) histological section of branch showing axis (a), siphonozooid (s), papilla (p), and solenial canals (c); (F) histological section of branch showing axis, siphonozooid, and solenial canals.

corresponding to tentacle bases extend to near the base of the polyp (Figure 2). Many autozooids appear biserially arranged, others occur singly and or in clusters of 3 or more. Autozooids may be more irregularly scattered on larger branches; most distributed on one side of the colony. Often biserial autozooid pairs seem to progressively separate when a branch grows and subsequently increases in width, giving the impression of polyp 'movement' toward opposite 'edges' of the branch. Higher order branches generally have more polyps per $\mathrm{cm}$ of branch length than lower order branches; the main axis has comparatively few polyps.

Colony surface prominently papillate, with papillae occurring singly or in clusters between autozooids, and varying in appearance from elongate, conical projections to short, raised 'bumps' (Figure $2 \mathrm{~B}$ ). Some papillae appear to have one or more pores that connect to a canal-like solenial system. Solenial channels originating at pores seem to interconnect with those of adjacent siphonozooids (Figure $2 \mathrm{C}$ (arrows), E, F) suggesting that papillae may somehow facilitate the flow of water through a colony. Developing reproductive cells reside exclusively in siphonozooids, and possibly in adjoining solenial channels.

Siphonozooids form small, rounded mounds with an apical pore and superficially resemble the short, 'bump' form of some papillae but are distinguished from the latter by the present of mesenteries. Siphonozooids primarily clustered at the autozooid bases, but are also present in the coenenchyme interspersed between autozooid polyps. On larger branches (1st and 2nd order) papillae and siphonozooids occur almost exclusively on same face of colony as autozooids and 


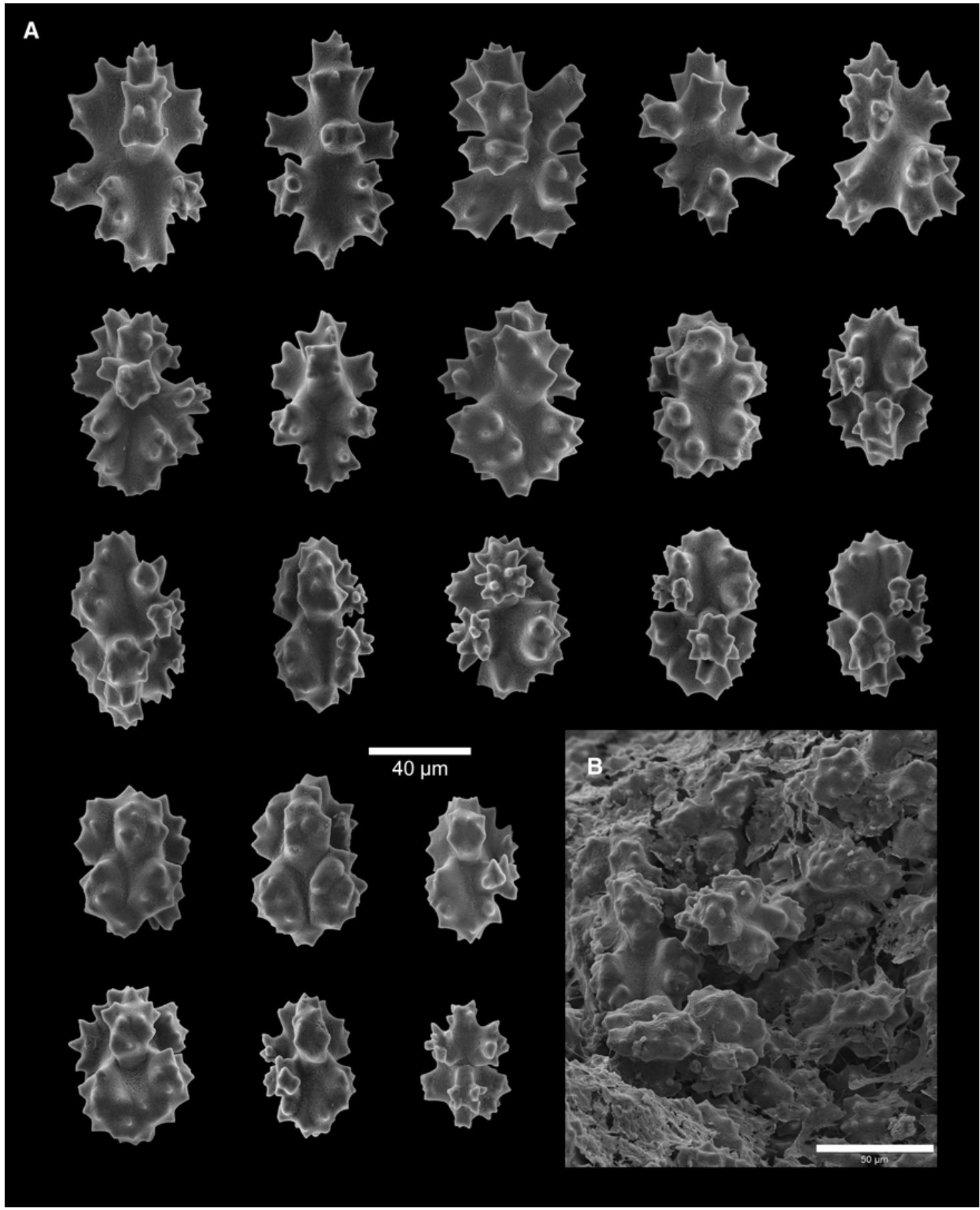

Fig. 3. Corallium bathyrubrum sp. nov. holotype. (A) Coenenchyme sclerites; (B) scanning electron microscopy image of sclerites on coenenchyme surface.

along sides of branches; on smaller branches ( $3 \mathrm{rd}$ and 4 th order) and branchlets these structures are distributed over the entire branch surface. Faint longitudinal striations or grooves occur on coenenchyme surface, especially on 'back' sides of largest branches; these surface features may be present but often not clearly visible on smaller branches and branchlets.

In contrast to overlying tissue, axial surface generally smooth and without striations, appearing granular under magnification with light microscope.

Predominant sclerite types in the coenenchyme are 6-, 7-, and 8-radiates; most highly modified, with irregular forms extremely common (Figures $3 \& 4$ ). Radiates vary in size from up to $0.070 \mathrm{~mm}$ in length for 6-radiates, and up to $0.090 \mathrm{~mm}$ in length for 7-, 8-radiate and irregular forms. A number of radiates appear asymmetrical, having apparent hypertrophic processes along with reduced, multilobular rays. These radiate-type sclerites bear slight resemblance to double clubs but are not so highly modified. Polyp wall sclerites do not appear to differ significantly from those present in branch coenenchyme. Tentacle sclerites are radiates, including irregular forms, and spiny rods up to $0.119 \mathrm{~mm}$ in length. Radiate forms occur along the aboral tentacle surface with two horizontal rows of spiny rods distributed along the oral surface. Occasional crosses (also known as 'twinned forms') 


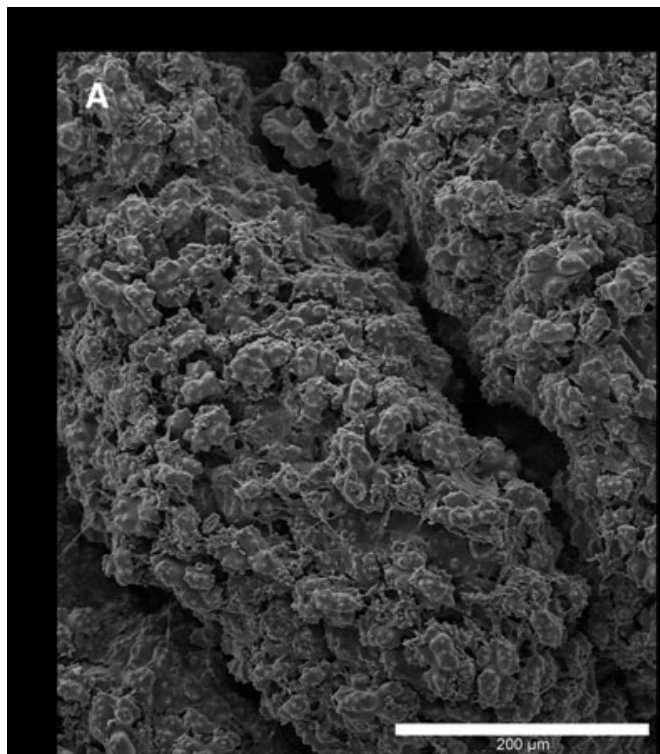

B
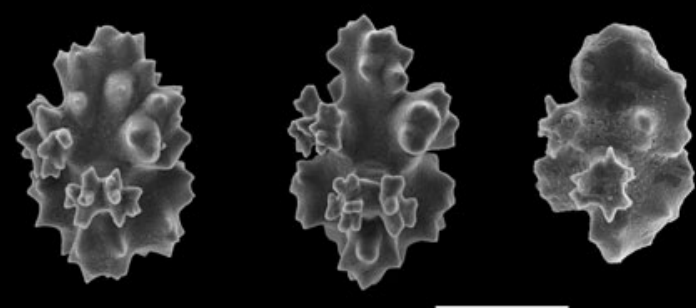

$40 \mu \mathrm{m}$
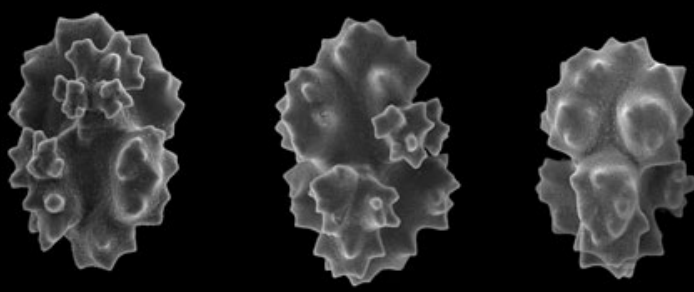

C
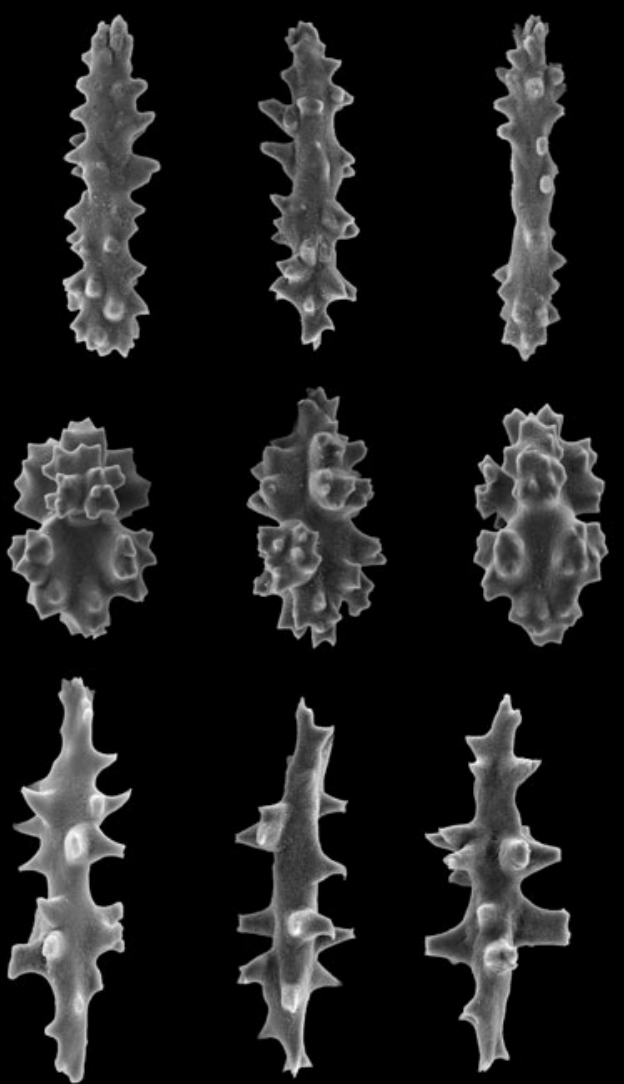
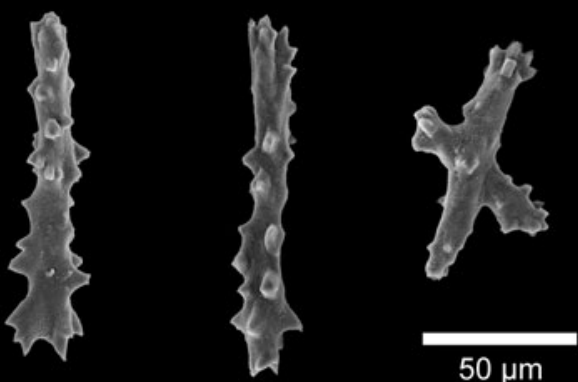

$50 \mu \mathrm{m}$
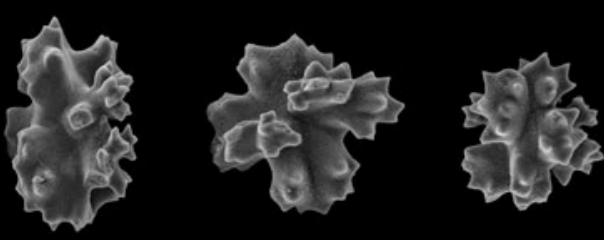
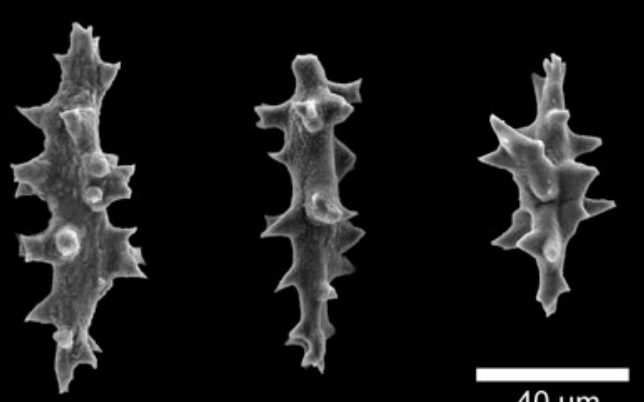

$40 \mu \mathrm{m}$

Fig. 4. Corallium bathyrubrum sp. nov. holotype. (A) Scanning electron microscopy image of sclerites on aboral surface of tentacles; (B) polyp sclerites; (C) tentacle sclerites; (D) pharyngeal sclerites.

may occur in coenenchyme, polyps, and tentacles but are relatively rare. Pharyngeal sclerites are spiny spindles up to $0.106 \mathrm{~mm}$ in length.

This species appears deep pink to almost red in colour when live; colour fades only slightly in ethanol and to a greater degree when dried. Axis colour deep pink to red; sclerites strongly pink in reflected light; individual sclerites only slightly pink to colourless when examined with a microscope under transmitted light.
VARIATION

Branching may be somewhat irregular in smaller colonies and colonies that have sustained physical damage. Longitudinal striations on the coenenchyme surface may be clearly visible, faint, or even absent on some colonies. The degree to which the coenenchyme surface is papillate may also vary widely between colonies as well as among different-sized branches within an individual colony, with larger branches being less densely papillate compared to smaller branches. 
There is some variation in the colour of the axis ranging from light to deep pink. Corallium bathyrubrum colonies may grow attached to the dead skeletons of other corals such as Desmophyllum dianthus and even other Corallium species.

\section{COMMENSALS/EPIPHYTES}

Relative to some other Corallium species, C. bathyrubrum is rather devoid of commensals. The only regularly occurring commensal were anemones of the genus Amphianthus (Acontiaria: Hormathiidae) found attached to mid and upper colony branches. Where tissue was missing, the usual fouling species such as hydroids or glyptelasmid barnacles were present.

\section{DISTRIBUTION}

This species is so far known only from the western Atlantic seamounts in the Corner Rise and New England Seamount groups. It seems to occur most frequently on brecciated substrate at depths from $2000 \mathrm{~m}-2500 \mathrm{~m}$.

\section{REMARKS}

Corallium bathyrubrum is the first red Corallium species reported from the western Atlantic and is most similar to the Pacific species C. regale. Corallium bathyrubrum differs from the latter species in having a relatively thin coenenchymal layer with numerous papillae, 8-lobed autozooid polyps with grooves that extend to the polyp base, in having fewer distinct 8-radiate sclerites, an absence of short, almost spherical 6-radiates, no true double clubs, and no apparent commensal polychaetes. Sclerites of $C$. regale examined by us also showed small processes on the protuberances of the radiates, a feature never seen on C. bathyrubrum. Sclerites from C. bathyrubrum resemble those of the sympatric species, C. niobe, however, the latter species differs from C. bathyrubrum in being white in colour and possessing slightly longer radiates and shorter pharyngeal spindles, and generally in having a greater proportion of 6- and 7-radiate sclerites. Additionally, the branches of $C$. niobe are frequently modified to form tunnels inhabited by a commensal polychaete. It seems clear there are several closely related species of Corallium in the Atlantic and Pacific, all differing from each other in small details. We predict that genetic work will show these species to be sister taxa.

\section{Corallium bayeri sp. nov.} (Figures 5-7)

\section{TYPE MATERIAL}

Holotype: Pickett Seamount, Station PIC 105-2, $39^{\circ} 39.266^{\prime} \mathrm{N}$ $65^{\circ} 55.689^{\prime} \mathrm{W}, 1970 \mathrm{~m}, 28$ October 2005, 2 broken branches off larger colony, $23.5 \mathrm{~cm}$ and $20 \mathrm{~cm}$ in length, YPM 38614 . Paratype: Nashville Seamount, Station NAS 201-6, 2529 m, $34^{\circ} 28.19^{\prime} \mathrm{N} 56^{\circ} 43.77^{\prime} \mathrm{W}, 25$ August 2005 , broken branch fragments, $25 \mathrm{~cm}$ maximum length, USNM No. 1135990.

\section{ETYMOLOGY}

Named in honour of the late Dr F.M. Bayer, eminent octocoral taxonomist, and supporter of young biologists.

\section{DIAGNOSIS}

Corallium with irregular branching in roughly a single plane. Autozooids generally tall and cylindrical; mostly directed towards one face of colony. Grooves formed by tentacle bases usually faint along outer polyp wall and often do not extend to base. Siphonozooids mainly distributed around autozooid polyp bases but may occur scattered on coenenchyme between polyps. Coenenchyme thin with surface uniformly covered by small, papillate bumps. Sclerites mostly double clubs with fewer, mostly irregular, radiate types. Autozooid polyp sclerites similar in form to those found in the coenenchyme except for two rows of horizontally oriented spiny rods that line the oral surface of the tentacles. Pharyngeal sclerites are spiny rods. Live colonies white with slightly pinkish polyps; ethanol preserved colonies white to slightly yellowish. Axis solid white, superficially smooth; sclerites colourless. Commensal polychaetes dwell in tunnels along surface of axial skeleton.

\section{DESCRIPTION}

Holotype: partial colony consisting of two broken branches (Figure 5B). Branches measure about $23 \mathrm{~cm}$ and $21 \mathrm{~cm}$ in length; both slightly curved. The longer branch tapers from $5.5 \mathrm{~mm}$ to $1.9 \mathrm{~mm}$ in diameter at the distal end. The other branch tapers from $5.25 \mathrm{~mm}$ to $3.0 \mathrm{~mm}$ in diameter and branch is broken at both ends. Both branches vary from slightly oval to round in cross-section and each with at least one intact smaller branch with sinuous form. Numerous small branchlets arise, especially from smaller branches, often in pinnate-like branching pattern. Branchlets are thin (approximately $0.5 \mathrm{~mm}-1.5 \mathrm{~mm}$ ) and bear up to 14 autozooid polyps; often terminal end of branchlet bears a pair of bifurcating polyps.

Autozooids more densely distributed on the smaller branches and branchlets, with nearly all polyps occurring on one side of colony. Polyps generally tall and mound-like or more cylindrically shaped (Figure $5 \mathrm{C}, \mathrm{D})$. Contracted calyces up to $2.85 \mathrm{~mm}$ in height and $1.65 \mathrm{~mm}$ wide at base. Tentacles fold over and extend down into oral region of the polyp in contracted state. Divisions between tentacles produce faint, longitudinal grooves on the upper region of the polyp; grooves generally do not extend to the polyp base. Siphonozooids appear as very small, rounded mounds $\left(\sim 0.125 \mathrm{~mm}\right.$ in diameter), with an apical pore (Figure ${ }_{5} \mathrm{~F}$ ). Most siphonozooid polyps surround the bases of autozooids. Reproductive cells develop in siphonozooids and possibly in adjacent solenial canals.

Close examination of coenenchyme surface reveals finely granular texture produced by arrangement of the outer sclerites. Small, raised bumps cover coenenchyme surface nearly uniformly on both the polyp-covered face and polyp-free side of the colony (Figure $5 \mathrm{C}$ ). Axial surface appears smooth when examined without magnification; very small raised bumps visible with light microscopy. Under SEM axial surface exhibits regularly spaced structures that resemble cone-like papillae and measure about $\sim 0.020 \mathrm{~mm}$ in height (Figure ${ }_{5} \mathrm{E}$ ). Some parts of axis may be modified to form tunnels occupied by a polychaete. Most tunnels have a thin, calcareous wall with an overlying layer of somewhat thickened coenenchymal tissues. One polychaete found in partial tunnellike channel formed by thickened walls of coenenchyme. All tunnels occur on same colony face as polyps.

Double clubs, irregular forms, and radiate types occur in the tissues forming wall of the polyp calyx and extend up along backs (aboral surface) of tentacles (Figure 6). Spiny rods $0.115 \mathrm{~mm}$ in length transversely stacked in parallel 

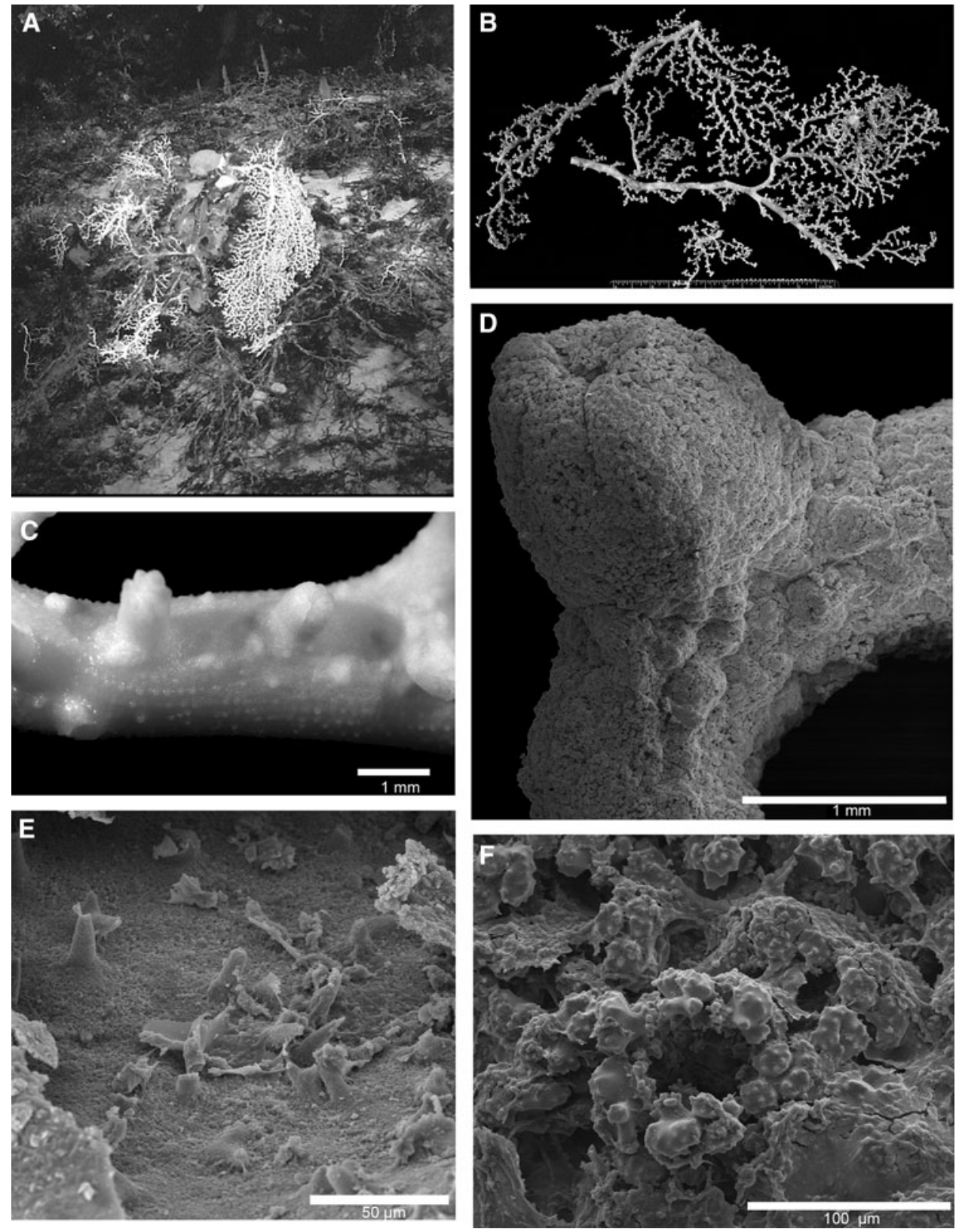

Fig. 5. Corallium bayeri sp. nov. (A) In situ view of paratype colony; (B) holotype colony photographed in the laboratory aboard ship; (C) close-up of colony surface showing polyps and papillae; (D) scanning electron microscopy (SEM) image of autozooid and siphonozooids; (E) SEM image of axial surface with cone-like papillae; (F) SEM image of siphonozooid apical pore.

rows towards oral surface of tentacles. Pharyngeal sclerites spindle-like and measure up to $0.082 \mathrm{~mm}$ in length with elongate, multi-point spiny projections (Figure 6). Double clubs most numerous sclerite type in coenenchyme where they intermix with irregular sclerites and radiate forms in thin layer overlying the axis (Figure 6B). 'Heads' of enlarged (or hypertrophied) rays sculpted with pointed and more bluntly shaped projections. These sclerites measure from $0.032 \mathrm{~mm} \times 0.041 \mathrm{~mm}$ up to $0.049 \mathrm{~mm} \times 0.085 \mathrm{~mm}$ with longer axis corresponding to widest area created by adjoining hypertrophied rays. Irregular sclerites and radiate forms present in the coenenchyme may reach length of up to $0.084 \mathrm{~mm}$.

Colony axis appears completely white in cross-section. Coenenchyme tissue and polyps light pink to almost white when live; however the colour of tissues changes to yellowishwhite after preservation. Sclerites colourless but appear white when casually examined.

\section{COMMENSALS/EPIPHYTES}

Larger branches modified by tunnels of the commensal polychaete Gorgoniapolynoe caeciliae (Fauvel, 1913). In addition, a commensal anemone can also be found on upper branches.

\section{DISTRIBUTION}

The only known specimens of this species have been collected from two seamounts (Picket at the western end and Nashville at the eastern end) in the New England Seamount Chain at depths of $1970 \mathrm{~m}-2529 \mathrm{~m}$. 


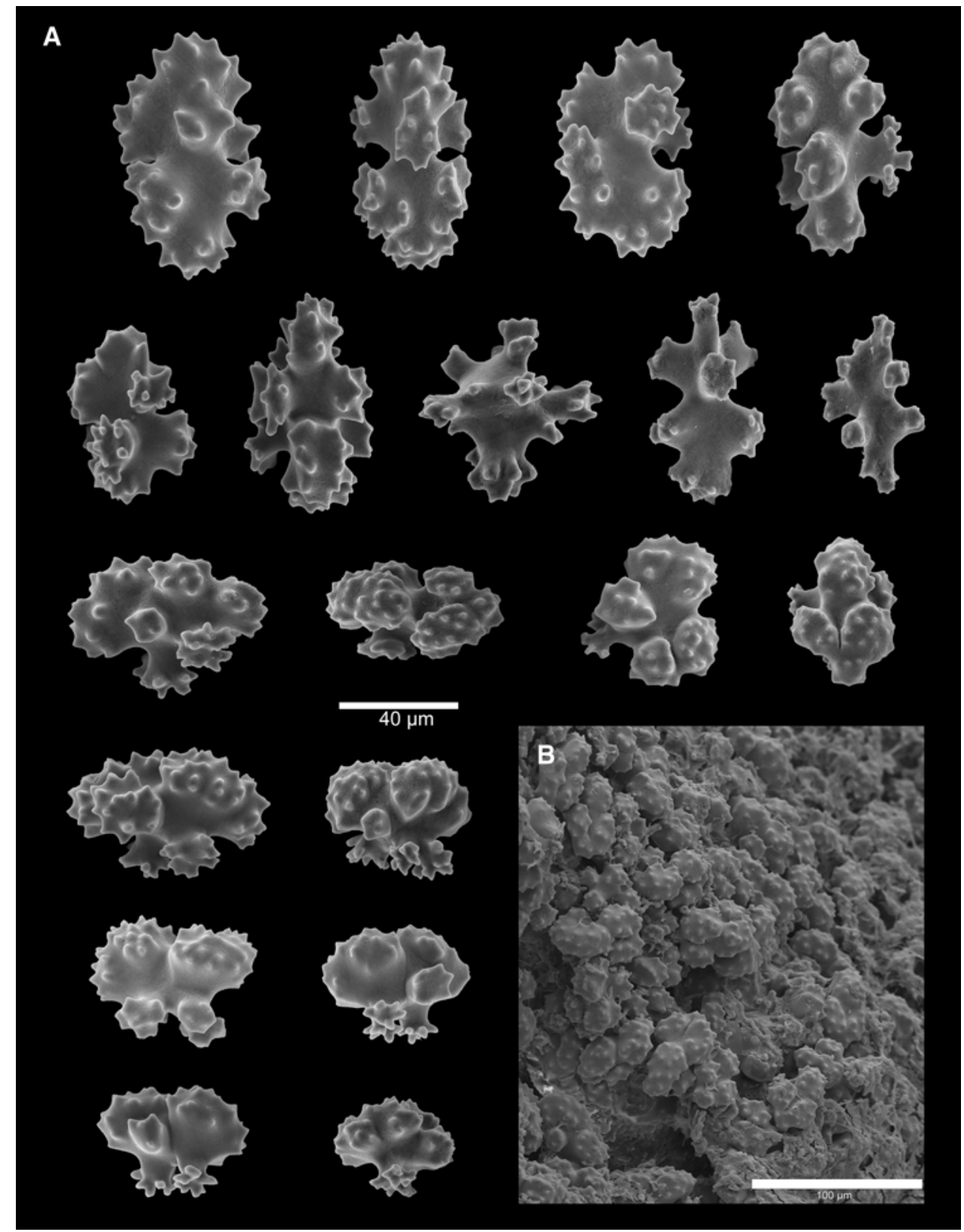

Fig. 6. Corallium bayeri sp. nov. holotype. (A) Coenenchyme sclerites; (B) scanning electron microscopy images of sclerites on coenenchyme surface.

\section{REMARKS}

Corallium bayeri, like other Corallium species collected from western Atlantic seamounts, often grows in patches with multiple colonies that may include one or more Corallium species. An in situ image of the paratype specimen (NAS 206-1) clearly shows the live colony growing from a base that is attached to a dead coral skeleton (Figure 5A) in a patch with other Corallium colonies. Based on the image it is not possible to determine if the dead coral skeleton was a large C. bayeri colony or whether the colony settled on and grew from the dead skeleton of another coral species.

This species is most similar to C. maderense, recorded from off Madeira in the eastern Atlantic and C. medea and C. niobe, two other Atlantic Corallium species with similar distributions. Corallium bayeri differs from C. maderense and C. medea in having slightly taller polyps, double clubs with hypertrophied rays that have numerous blunt and pointed projections, giving the 'heads' a jagged-edged, irregular appearance, and a longitudinal sclerite axis that is always longer than the transverse axis. It differs further from C. maderense in the lower degree of branch density, colour of the live colony, and lack of 'ball-like' sclerites in the cortex. It further differs from $C$. medea in possessing spiny rods in the tentacles, and in harbouring a commensal polychaete. Corallium bayeri differs from C. niobe in having numerous double clubs, autozooids with grooves that do not extend to the polyp base, and no faint striation of the axial surface, but is similar in being colonized and modified by commensal worms.

Corallium niobe Bayer, 1964

(Figures 8 \& 9) 


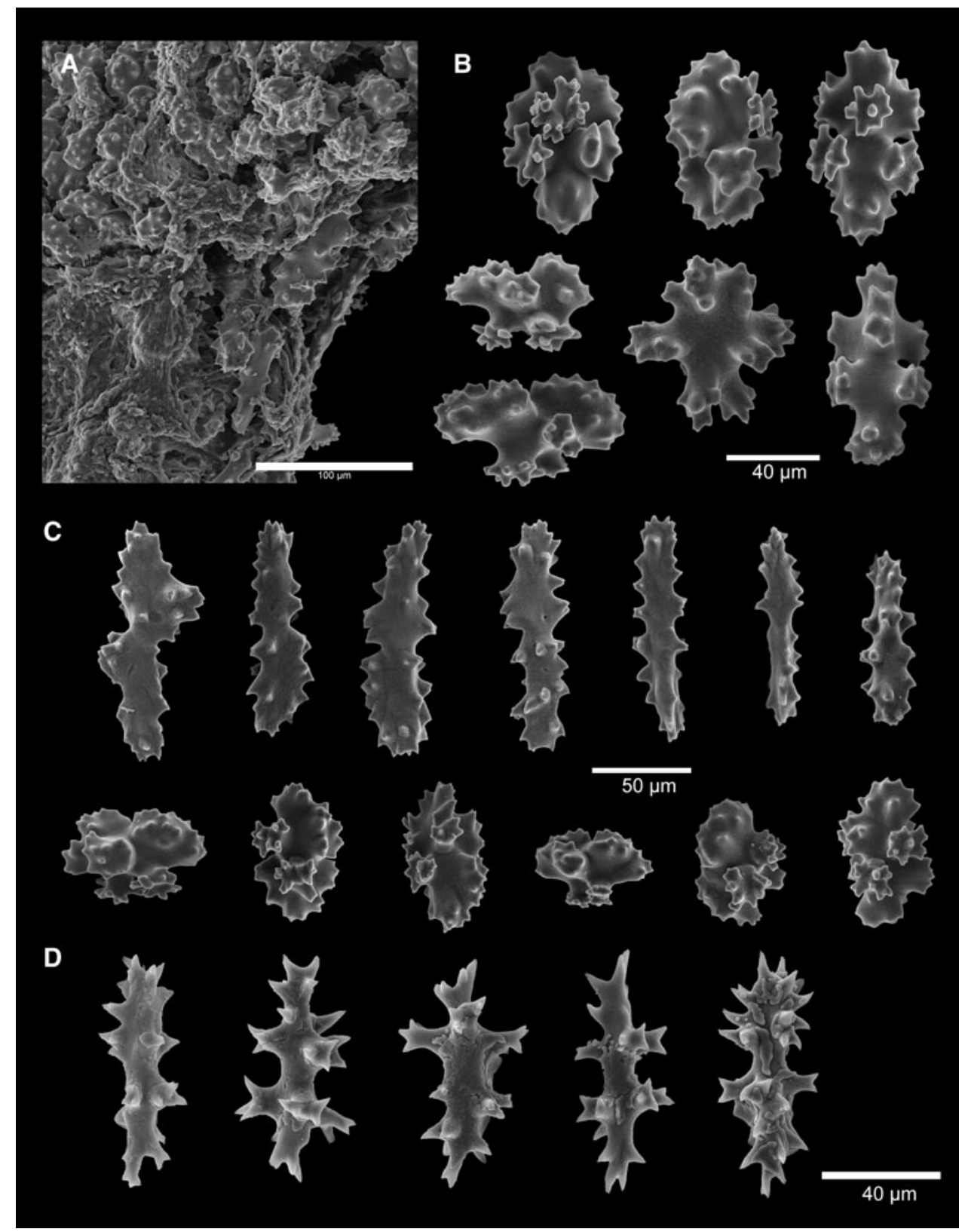

Fig. 7. Corallium bayeri sp. nov. holotype. (A) Scanning electron microscopy image of sclerites on lateral and oral tentacle surface; (B) polyp sclerites; (C) tentacle sclerites; (D) pharyngeal sclerites.

TYPE MATERIAL

Holotype: RV 'Gerda' cruise 6333, haul G-170, off Straits of Florida, east of St Lucie Inlet, Florida, $27^{\circ} 06^{\prime} \mathrm{N} 79^{\circ} 32^{\prime} \mathrm{W}$, 677-659 m, otter trawl, 29 June 1963, broken branches only, USNM No. 52515.

\section{OTHER MATERIAL EXAMINED (NON TYPE)}

Kelvin Seamount, Station 204-1, $38^{\circ} 51.411^{\prime} \mathrm{N} 63^{\circ} 54.881^{\prime} \mathrm{W}$, $2041 \mathrm{~m}, 16$ July 2003, fragment, YPM 26811; Kelvin Seamount, Station $207-1,38^{\circ} 51.082^{\prime} \mathrm{N} 63^{\circ} 55.339^{\prime} \mathrm{W}, 1902 \mathrm{~m}$, 16 July 2003, fragment, YPM 28690, 34728; Kelvin Seamount, Station KEL 209-2, $38^{\circ} 50.992^{\prime} \mathrm{N} 63^{\circ} 55.572^{\prime} \mathrm{W}$, $1859 \mathrm{~m}, 16$ July 2003, nearly whole colony, $29 \mathrm{~cm}$ in height and $20 \mathrm{~cm}$ wide, YPM 28622, 28722, 34719, 36251; Goode Seamount, Station GOO 114-1, $35^{\circ} 23.65^{\prime} \mathrm{N} \quad 51^{\circ} 16.33^{\prime} \mathrm{W}$, 1879 m, 21 August 2005, three broken branches off larger colony, $11.7 \mathrm{~cm}, 11.4 \mathrm{~cm}$, and $9.8 \mathrm{~cm}$ in length, $\mathrm{YPM} 38617$; Kelvin Seamount, Station KEL 618-1, $38^{\circ} 46.25^{\prime} \mathrm{N}$ $64^{\circ} 05.30^{\prime} \mathrm{W}, 1846 \mathrm{~m}, 1$ September 2005 , whole colony with partial holdfast, $18.3 \mathrm{~cm}$ in length and $34.2 \mathrm{~cm}$ wide; YPM 38618; Balanus Seamount, Station BAL 203-1, $39^{\circ} 24.93^{\prime} \mathrm{N}$ $65^{\circ} 24.67^{\prime} \mathrm{W}, 1911 \mathrm{~m}, 2$ September 2005 , partial colony, $20.3 \mathrm{~cm}$ in length and $28.2 \mathrm{~cm}$ wide, YPM 38619; Pickett Seamount, Station PIC $105-4,39^{\circ} 39.228^{\prime} \mathrm{N} 65^{\circ} 56.909^{\prime} \mathrm{W}$, $1970 \mathrm{~m}, 20$ October 2005, broken branch fragments, $19.8 \mathrm{~cm}, 13.4 \mathrm{~cm}$, and 9.4 in length, YPM 38616.

\section{DIAGNOSIS}

Modified from Bayer (1964). Primary branching 'irregularly pinnate'; higher order branches arise more or less in a dichotomous pattern. Branching most often in one plane but with occasional branches perpendicular to or otherwise departing 

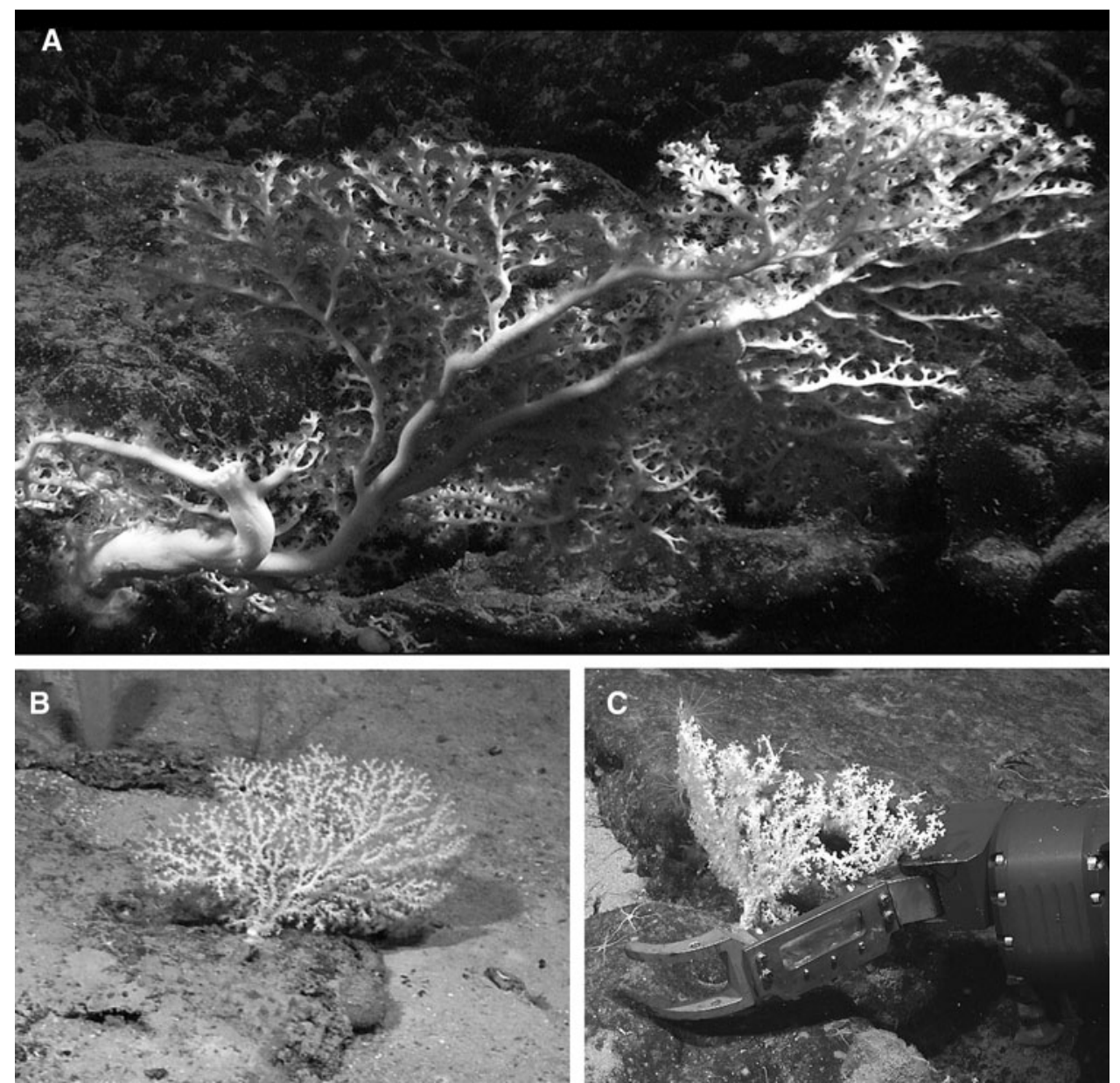

Fig. 8. Corallium niobe Bayer, 1964. (A) In situ view of colony (BAL 203-1) on Balanus Seamount at $1911 \mathrm{~m}$; (B) in situ view of colony (GOO 114-1) on Goode Seamount at $1879 \mathrm{~m}$; (C) colony (KEL 618-1) being collected on Kelvin Seamount at $1846 \mathrm{~m}$.

from the dominant plane of growth; anastomosing branches occurs infrequently. Autozooids mainly distributed on one side of colony. Contracted polyps tall and cylindrical, up to $2 \mathrm{~mm}$ in height and $1.5 \mathrm{~mm}$ in diameter with eight grooves corresponding to tentacle bases extending entire length of polyp. Siphonozooids nearly indistinguishable from low papillae and scattered about on the surface of the branch, but most commonly near autozooids. Axial surface smooth and without pits, minutely granular under magnification with the stereomicroscope. Coenenchyme layer overlying axis extremely thin with small papillae often arranged in longitudinally-oriented rows. Most common sclerite type in coenenchyme is 8-radiates, many modified; 6- and 7-radiate forms also present but less common. Tentacle sclerites spinous rods; pharyngeal sclerites spiny and spindle-like. Coenenchyme tissue slightly pink when live, fades to a yellowish white after preservation in ethanol; axis 'snowy white' in colour. Branches often modified by tunnels created by the commensal polychaete, Gorgoniapolynoe caeciliae.

\section{DESCRIPTION}

Modified from Bayer (1964) with additions. Colonies may be distinctly fan-shaped (e.g. GOO 114-1, KEL 618-1). Colony branching characteristics vary from mostly irregular to generally pinnate, with a shift to a more dichotomous pattern on smaller/higher order branches. Branching mostly in one plane but occasionally growth occurs at an acute angle resulting in overlapping branches. Growth may also occur almost perpendicular to the general colony plane. Anastomosing branches appear to be rare but are present in one colony having branches that depart from the planar growth pattern. Maximum recorded colony size approximately $70 \mathrm{~cm}$ in height and $50 \mathrm{~cm}$ wide (BAL 203-1 in situ colony measurements). Colonies anchored to exposed basaltic bedrock by a holdfast that progressively widens towards the base to cover the substrate with a thin layer of calcareous tissue. Central 'trunk' or colony axis nearly circular in crosssection and measured (in situ) about $3.4 \mathrm{~cm}$ in diameter on the largest colony collected (BAL 203-1). Colonies have from 2 to 4 main or 'primary' branches arising from the main axis. Additional branching occurs up to 5th order; branches round to slightly oval in cross-section, progressively tapering to smaller diameter with increasing branch order. Terminal branchlets with tunnels produced by a commensal polychaete flatten to a 'blade-like point' as noted by Bayer (1964). Small branchlets with 6 or fewer autozooid polyps generally numerous over entire colony.

Most autozooid polyps arise from one side of a colony and one predominantly distributed on secondary and higher order branches and branchlets, notably tall and cylindricallyshaped, with 8 prominent longitudinal grooves that extend along the length of the polyp. When contracted, the tentacles fold over the oral disc. In contracted state, autozooids measure up to $2.6 \mathrm{~mm}$ in height and $1.6 \mathrm{~mm}$ wide at their base. 


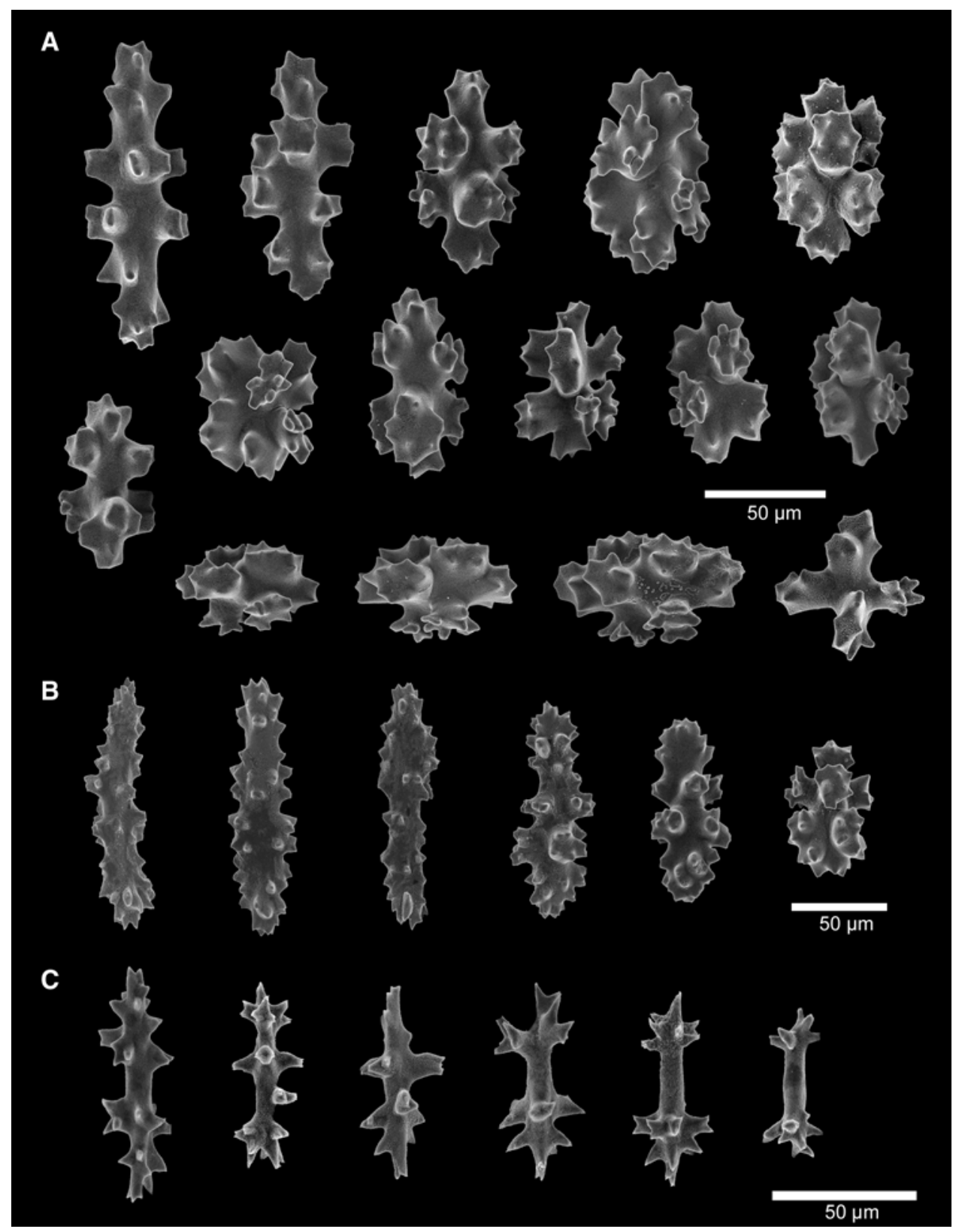

Fig. 9. Corallium niobe Bayer, 1964. (A) Coenenchyme sclerites; (B) tentacle sclerites; (C) pharyngeal sclerites.

Siphonozooids small, slightly raised protuberances on the surface of the branch tissue, occurring in clusters near autozooids. Other small protuberances appear to be surface openings of solenial canals. Coenenchyme layer between autozooids thin and varies from finely granular, especially on the autozooid 'face' of the colony, to faintly striated with low, thin ridges, to subtly papillate with small, low papillae arranged into longitudinally-oriented rows usually on the 'back' or autozooid-free face of colony. When tissues are dried resulting shrinkage renders all coenenchyme surface features more visible. Axial surfaces, like some areas of coenenchyme surface, finely granular but otherwise generally smooth and without pits or ridges.

Coenenchyme sclerites mostly 8-radiate capstans with tubercular projections that are either fairly blunt or bear dull, conically-shaped points; 6-, and 7-radiates also present but much less common (Figure 9). Crosses (i.e. 'twinned forms') extremely rare. Irregular radiate forms not uncommon and include asymmetrical sclerites. This latter form possesses apparent hypertrophied processes, usually formed along one side of the longitudinal sclerite axis, and reduced, often multilobular rays or projections opposing the enlarged tubercles. The enlarged 'rays' or processes on these radiates are not smooth. Bayer (1964) noted that these '...outermost rays [are] somewhat enlarged but not enough to produce double clubs.' Radiate sclerites may reach a length of up to $0.1 \mathrm{~mm}$.

Autozooid polyp sclerites include radiates, spiny rods and spindles (Figure 9). Radiate forms occur around the polyp base and continue up the outer polyp wall, becoming reduced in size as they cover the aboral surface of the tentacles. On the oral surface of the tentacle radiates are replaced by horizontally abutting rows of spiny rods. Tentacle sclerites up to $0.125 \mathrm{~mm}$ in length. Smaller elongate sclerites in the form of spiny spindles occur only in pharyngeal region of 
the polyp. Pharyngeal sclerites may be as long as $0.07-$ $0.08 \mathrm{~mm}$ in length.

Freshly collected and unfixed colonies of C. niobe have white to lightly pink coenenchyme. After preservation with ethanol coenenchyme varies from white to slightly yellowish in appearance. Skeletal axis 'snowy white'; sclerites colourless.

\section{DISTRIBUTION}

This species has been recorded from the Florida shelf and a number of seamounts in the north-western Atlantic Ocean. It was first described from the Straits of Florida and is known from the Bahamas and the New England Seamount Chain and Corner Rise Seamount Group at depths of 659 m-1970 m.

\section{REMARKS}

Colonies collected from western Atlantic seamounts closely resemble the colony described by Bayer (1964) from the Straits of Florida with only a few minor exceptions. Seamount colonies generally possessed slightly longer tentacles sclerites (up to $0.145 \mathrm{~mm}$ in length) and did not appear to have faint striations on the axis as noted on the holotype. Only branches where worm tubes were present tapered to a 'fine, blade-like point'.

\section{DISCUSSIDN}

Since the genus Corallium was erected by Cuvier in 1798 it has undergone a number of taxonomic revisions that have variously redefined the number of species it includes. Gray (1867) divided the genus into three genera, Corallium, Hemicorallium and Pleurocorallium, based on autozooid distribution and branching characteristics. Later, Ridley (1882) recognized only Corallium and Pleurocorallium as valid, uniting Hemicorallium with the latter genus. Ridley attributed species with 'opera glass' or 'double club' sclerites to Pleurocorallium while those lacking such sclerites were assigned to Corallium. In his comprehensive systematic work on Coralliidae from Japanese waters, Kishinouye (1904) disputed the existence of multiple genera in the family Coralliidae. Most later authors agreed with Kishnouye's conclusion and Corallium remained the only valid genus in the family Coralliidae until 2003 when Bayer \& Cairns (2003) erected Paracorallium to differentiate a distinct group of 7 coralliid species characterized by a unique mode of axis formation.

Within the genus Corallium Kishinouye (1904) and later Bayer (1956) recognized a number of morphologically related subgroups; however, neither author entirely succeeded in developing a more detailed classification scheme based on the characters used in their independent analyses of the genus. In his 1956 paper on Hawaiian octocorals Bayer identified characteristics for 4 subgroups but prefaced his observations with the following paragraph (p.74):

'...Disregarding the sad experiences of others I attempted anew to bring these groups into some logical arrangement. This has proven even more hopeless than it was half a century ago when Kishinouye studied the problem. After long and serious consideration I can do no more than to point out certain of the relationships in the hope that some eye more penetrating than my own may detect among them a clue to the solution.'
One of Bayer's four subgroups characterized by '... species that have pits in the axis beneath the autozooids' later became the new genus Paracorallium (Bayer \& Cairns, 2003). Another subgroup including the species C. konojoi, C. borneense, C. niveum and C. pusillum, is distinguished by a thick coenenchyme layer, hemispherically-shaped autozooid polyps occurring in clusters, and double club sclerites. A third subgroup is characterized having a papillate coenenchyme, hemispherically-shaped autozooid polyps, and double club sclerites. The final subgroup proposed by Bayer (1956) encompassed 'a perplexing array of species characterized by one feature: long spindles in the autozooid verrucae, which are usually tall.'

Corallium niobe and the two new species described herein appear to fit into this final, ill-defined subgroup. They all share similar polyp shape and sclerite form but differ from each other and all other known species in having unique combinations of colour, branch pattern, coenenchyme and polyp features, and variations in sclerite size and form.

Our studies of whole branches with SEM have shown that features that have been termed 'siphonozooids' in the older taxonomic literature will need to be re-examined. It is clear that some of the smaller mounds with pores are simply solenial canals opening at the surface of the coenenchyme. We have looked into many of these openings at high magnification and have seen no indication of mesenteries. In some cases mesenteries are clearly present, so without a close examination it may not be possible to know how frequent siphonozooids really are.

Corallium niobe and C. bayeri colonies both harbour the commensal polychaete, Gorgoniapolynoe ceceilae (Fauvel, 1913), living in tunnels formed by modifications to the coenenchyme along the branches of the host colony. This polychaete also lives on colonies of the primnoid octocoral, Candidella imbricata (Johnson, 1862) (Eckelbarger et al., 2005). The presence of invertebrate commensals on selected octocoral species from the deep-sea suggests the existence of species-specific commensal-host relationships. It is possible that the unique metabolic characteristics of particular coral species create a chemical and physical environment that is suitable to, or tolerable by, a few species of commensal invertebrate(s). If a specific relationship between coral host and invertebrate commensal exists for Corallium species, then the presence of a commensal species may provide an additional taxonomic character for identification of certain deep-water coral species.

Representatives of the genus Corallium are found in most of the world's oceans from shallow $\left(<_{10} \mathrm{~m}\right)$ to deep $(>2000 \mathrm{~m})$ waters. A number of these species, especially those occurring at more shallow depths, have been subject to commercial harvesting that has resulted in steep declines in coral populations (e.g. Grigg, 1994; Santangelo \& Abbiati, 2001). As shallow-water Corallium populations diminish, exploitation of deeper coral species may increase along with need to document deep-water Corallium diversity. Effective conservation strategies for these populations will need to be developed before exploitation should be allowed.

\section{ACKNDWLEDGEMENTS}

This work was made possible by generous funding provided by the NOAA Ocean Exploration programme. We would 
like to thank L. Watling's co-principal investigators, P. Auster, S. France, I. Babb, L. Mullineaux, J. Moore and K. Scanlon for their help in securing the necessary funding to allow us to explore north-western Atlantic seamount communities. Our sincere thanks to the captains and crew of the RV 'Atlantis' and the NOAA ship 'Ronald H. Brown', who together with the skilful pilots of the DSV 'Alvin' and ROV 'Hercules', made it possible to collect high quality imagery and specimens from great depths. We are very grateful to S. D. Cairns at the Smithsonian Natural History Museum for sharing his expertise in addition to his notes and SEM images of $C$. niobe and $C$. bathyrubrum sclerites. S.D. Cairns also assisted us in accessing museum collections as well as the papers of the late F. Bayer. We are also indebted to T. Carvalho at the University of Hawaii PBRC Electron Microscope Facility for her assistence with the scanning electron microscope. This work benefited from the generosity of V. Radashevsky who translated the description of $C$. porcellanum from Russian to English. M. Petersen provided literature and assistance with commensal polychaete identification, C. Mosher with specimen preservation and $\mathrm{H}$. Yilito-Ward helped with SEM imaging. We are especially indebted to the late Dr F.M. Bayer who encouraged our initial forays into octocoral taxonomy.

\section{REFERENCES}

Baco A.R. and Shank T.M. (2005) Population genetic structure of the Hawaiian precious coral Corallium lauuense (Octocorallia: Coralliidae) using microsatellites. In Freiwald A. and Roberts J.M. (eds) Cold-water corals and ecosystems. Berlin: Springer-Verlag, pp. $663-678$.

Bayer F.M. (1950) A new precious coral from North Borneo. Journal of the Washington Academy of Sciences 40, 59-61.

Bayer F.M. (1955) Contributions to the nomenclature, systematics, and morphology of the Octocorallia. Proceedings of the United States National Museum 105, 207-220.

Bayer F.M. (1956) Descriptions and redescriptions of the Hawaiian octocorals collected by U.S. Fish Commission steamer 'Albatross' (2. Gorgonacea: Scleraxonia). Pacific Science 10, 67-95.

Bayer F.M. (1964) The genus Corallium (Gorgonacea: Scleraxonia) in the western North Atlantic Ocean. Bulletin of the Marine Sciences of the Gulf and Caribbean 14, 465-478.

Bayer F.M. (1996) Three new species of precious coral (Anthozoa: Gorgonacea, genus Corallium) from Pacific waters. Proceedings of the Biological Society of Washington 109, 205-228.

Bayer F.M. and Cairns S.D. (2003) A new genus of the scleraxonian family Coralliidae (Octocorallia: Gorgonacea). Proceedings of the Biological Society of Washington 116, 222-228.

Carpine C. and Grasshoff M. (1975) Les gorgonaires de la Méditerranée. Bulletin de l'Institute Océanographique, Monaco 71, 1-140.

CITES (2007) Consideration of proposals for amendment of appendices $i$ and ii. Available from http://www.cites.org/eng/cop/14/prop/ E14-P21.pdf
Dana J.D. (1846) Zoophytes. United States Exploring Expedition during the years 1838,1839, 1840,1841, 1842, under the command of Charles Wilkes, U.S.N. 7, 1-740.

Eckelbarger K.J., Watling L. and Fournier H. (2005) Reproductive biology of the deep-sea polychaete, Gorgoniapolynoe caeciliae (Polynoidae), a commensal species associated with octocorals. Journal of the Marine Biological Association of the United Kingdom $85,1425-1433$.

Gray J.E. (1860) Description of a new coral (Corallium johnsoni) from Madeira. Proceedings of the Zoological Society of London 1860, 393-394.

Gray J.E. (1867) Additional note on Corallium johnsoni. Proceedings of the Zoological Society of London 1867, 125-127.

Grigg R.W. (1994) History of the precious coral fishery in Hawaii Precious Corals and Octocoral Research 3, 1-18.

Hickson S.J. (1907) Die Alcyonidae der Siboga Expedition. I. Coralliidae. Siboga Expeditie Monograph 13c, 1-8.

Johnson J.Y. (1899) Notes on the Coralliidae of Maderia, with descriptions of two new species. Proceedings of the Zoological Society of London 1899, 57-63.

Kishinouye K. (1903) Preliminary note on the Coralliidae of Japan Zoologischer Anzeiger 26, 623-626.

Kishinouye K. (1904) Notes on the natural history of corals. Journal of the Imperial Fisheries Bureau 14, 1-32.

Liverino B. (1983) Il corallo, esperienze e ricordi di un corallo. Bologna: Banca di Credito Popolare, Torre del Greco, Li Causi Editore.

Parrish F.A. and Baco A.R. (2007) State of deep coral ecosystems in the U.S. Pacific Islands region: Hawaii and the U.S. Pacific territories. In Lumsden S.E., Hourigan T., Bruckner A.W. and Dorr G. (eds) The state of deep coral ecosystems of the United States. NOAA Technical Memorandum CRCP-3, Silver Spring, Maryland, USA, pp. 165-194.

Pasternak F.A. (1981) Alcyonacea and Gorgonacea. In Kuznetsov A.P. and Mironov A.N. (eds) Benthos of the submarine mountains Marcus-Necker and adjacent Pacific regions. Moscow: Akademiya Nauk, pp. $40-55$.

Ridley S.O. (1882) On the arrangement of the Coralliidae, with descriptions of new or rare species. Proceedings of the Zoological Society of London 1882, 221-233.

Santangelo G. and Abbiati M. (2001) Red coral: conservation and management of an overexploited species. Aquatic Conservation: Marine and Freshwater Research 11, 253-259.

and

Thomson J.A. and Henderson D.L. (1906) An account of the alcyonarians collected by the Royal Indian Marine Survey Ship Investigator in the Indian Ocean. Part 1. The Alcyonarians of the deep sea. Calcutta: The Indian Museum, $132 \mathrm{pp}$

\section{Correspondence should be addressed:}

L. Watling

Department of Zoology

University of Hawaii at Manoa

Honolulu, HI 96822, USA

email: watling@hawaii.edu 